Recenzowana monografia stanowi nie tylko vademecum bazowych dla pedagogiki rodziny zagadnień ujętych w świetle pedagogiki personalistycznej, prezentowanej przede wszystkim w odniesieniach do personalistycznej myśli Jana Pawła II. Jest ona także niezwykle aktualnym przeglądem uwarunkowań - szans i zagrożeń - rozwoju dzieci i rodziny, opisuje bowiem zmiany zachodzące $\mathrm{w}$ XXI wieku związane $\mathrm{z}$ globalizacją, transformacją systemową i mediatyzacją życia społecznego i rodzinnego. Egzemplifikując, autorka ukazuje dzieciństwo medialne jako oblicze funkcjonowania dziecka w świecie zdominowanym przez media elektroniczne, które dzisiaj są jednym z pierwszych instrumentów jego eksploracji. Ponadto przedstawia alternatywne struktury małżeńsko-rodzinne, takie jak kohabitacja, rodzina diasporowa, rodzina bezdzietna $\mathrm{z}$ wyboru, rodzina zrekonstruowana po rozbiciu, małżeństwa byłych księży katolickich, małżeństwa osób młodocianych, małżeństwa osób niepełnosprawnych czy małżeństwa mieszane kulturowo.

Książka stanowi cenną lekturę i jest warta polecenia, zwłaszcza jako podręcznik dla studentów nauk społecznych, szczególnie zaś tych, którzy podejmują się zarówno pracy badawczej w ramach studiów pedagogicznych, jak i praktyki edukacyjnej w formie pracy z dzieckiem i rodziną. Uznana za wartościową winna być również przez rodziców, nauczycieli, wychowawców, duszpasterzy, słowem - wszystkich, którzy z różnych względów troszczą się o optymalny rozwój dziecka oraz o wychowanie rodzinne bazujące na uznaniu autonomicznej wartości osoby.

Marta Samorańska*

\title{
Sabina L. Zalewska, Relations and marriage bond in the empty nest syndrom, Warszawa: Wydawnictwo Uniwersytetu Kardynała Stefana Wyszyńskiego, 2014, Ss. 158.
}

DOl: http://dx.doi.org/10.12775/PCh.2015.020

Przed przystąpieniem do lektury książki Sabiny L. Zalewskiej warto sięgnąć po Metafizykę moralności Immanuela Kanta. Mimo że wielki filozof z Królewca nie był żonaty ani nie pozostawił po sobie potomstwa, to jednak w paragrafach od 22 do 30 wskazanego dzieła przedstawił, jak mi się

* Mgr Marta Samorańska jest doktorantką w Katedrze Pedagogiki Rodziny na Wydziale Nauk Społecznych Katolickiego Uniwersytetu Lubelskiego Jana Pawła II. Adres: In- 
wydaje, trafną, a co najmniej wartą rozważenia filozoficzną interpretację specyfiki więzi małżeńskiej w czasach współczesnych. Więź ta opiera się na dobrowolnej umowie zawieranej przez narzeczonych wchodzących w związek małżeński. Podobnie jak w różnego rodzaju transakcjach handlowych, również tutaj istotną rolę odgrywa przedmiot porozumienia, gdyż on właśnie będzie stanowił fundament wspólnoty małżeńskiej i rodzinnej (domowej). Konstytuujące dla tego przedmiotu jest obopólne zobowiązanie do tego, żeby „dawać” swoją wolę i „brać” wolę drugiej strony. Ta wzajemna wymiana stanowi, zdaniem królewieckiego mędrca, istotę związku małżeńskiego od strony filozoficznej ${ }^{1}$.

W tym kontekście warto zauważyć, że według I. Kanta podobna umowa odróżnia nowożytne wychowanie od jego form wcześniejszych. Umowę tę w niepisany sposób zawierają między sobą rodzice i dziecko. Jednak w tym przypadku chodzi o wolę tylko jednej strony - dziecka. Obrazowo mówiąc, wola ta zostaje powierzona rodzicom niejako w depozyt („tak jakby rzecz”) na ściśle określony czas, to jest do osiagniecia dorosłości, i w ściśle określonych warunkach. Odnośnie do tego ostatniego najważniejsze jest, że zlecone rodzicom władanie dziecięcą wolą nie powinno dokonywać się w sposób despotyczny ani hegemoniczny, lecz taki, żeby wola ta coraz więcej partycypowała w sprawowaniu władzy rodzicielskiej, przechodząc ze stanu heteronomii do autonomii ${ }^{2}$.

Z powyższego odwołania do myśli I. Kanta chciałbym wysnuć tylko jeden wniosek: w czasach współczesnych każde małżeństwo charakteryzuje się równocześnie stałością i dynamizmem. Na obie te „cechy” wywierają wpływ czynniki zarówno zewnętrzne, jak i wewnętrzne. Co prawda w naukach społecznych, takich jak psychologia, socjologia czy pedagogika (rodziny), analizowane są te uwarunkowania, jednak w ostateczności jakość relacji małżeńskich zależy od samych zainteresowanych, a dokładniej - od tego, w jaki sposób obchodzą się oni z powierzoną sobie wolą współmałżonka. Ponieważ problem ten jest trudny do penetracji naukowej, tym bardziej warto zapoznać się z opracowaniem S. L. Zalewskiej.

$\mathrm{W}$ napisanej w języku angielskim książce przedstawiono naukowy opis $\mathrm{i}$ interpretację zmian zachodzących $\mathrm{w}$ małżeństwie po opuszczeniu domu

stytut Pedagogiki KUL, ul. Droga Męczenników Majdanka 70, 20-325 Lublin; e-mail: marta. samoranska@o2.pl.

${ }^{1}$ Immanuel Kant, Metafizyka moralności (Warszawa: Wydawnictwo Naukowe PWN, 2007), 107-118.

2 Tamże, 115-116. 
rodzinnego przez dorosłe czy dorastające dzieci. W literaturze przedmiotu zespół objawów właściwych temu zjawisku opatruje się mianem syndromu pustego gniazda (empty nest syndrom). Autorka dąży do wychwycenia nie tylko jego determinantów zewnętrznych, lecz również wewnętrznych. Kluczowe znaczenie $\mathrm{w}$ jej sposobie patrzenia na małżeństwo ma wprowadzone we wstępie rozróżnienie między relacjami (relations) a więzią małżeńską (marriage bond). Filozoficznych źródeł tego rozróżnienia należy doszukiwać się w przywołanej powyżej koncepcji I. Kanta. Sama autorka odwołuje się jednak do wizji małżeństwa wynikającej z jej kato-lickiego punktu widzenia, a mianowicie jako związku sakramentalnego. To umożliwia jej wyodrębnienie w analizowanym zjawisku elementów stałych i zmiennych. Tego, co stałe, S. L. Zalewska dopatruje się w sakramentalnie ugruntowanej wspólnocie małżeńskiej (współcześnie należałoby jeszcze dodać: dwojga osób różnej płci), natomiast zmienności w relacjach, które ongiś zdefiniowane wymagają zredefiniowania po opuszczeniu przez dzieci rodzinnego gniazda.

Recenzowana monografia składa się z dwóch części. W pierwszej zainteresowany czytelnik znajdzie prezentację badań przeprowadzonych przez autorkę odnośnie do syndromu opuszczonego gniazda (s. 7-60). Drugą część tworzy sześć aneksów (s. 64-158). W pierwszym i drugim zostały zaprezentowane narzędzia badawcze wykorzystane w trakcie badania terenowego. Są to w szczególności: Skala Bliskości Małżonków autorstwa Marii Ryś i Skala Syndromu Opuszczonego Gniazda, którą opracowała autorka. W aneksach od trzeciego do piątego zamieszczono artykuły S. L. Zalewskiej opublikowane uprzednio w języku polskim, które teraz ukazują się w przekładzie na język angielski. Niestety, przy przetłumaczonych artykułach autorka nie podaje, gdzie je pierwotnie wydrukowano. Szósty aneks zawiera słownik najważniejszych terminów użytych w pracy.

W skład pierwszej części wchodzą: wstęp, pięć rozdziałów tematycznych, zakończenie i wykaz literatury cytowanej. We wstępie, oprócz wskazanego powyżej rozróżnienia między relacjami a więzią małżeńską, S. L. Zalewska wyodrębnia za Józefem Szopińskim trzy sfery kształtowania się relacji małżeńskich. Są to: sfera emocjonalna, intelektualna i działaniowo-dążeniowa. Następnie w odniesieniu do każdej z tych trzech sfer analizuje zmiany dokonujące się w małżeństwie po usamodzielnieniu się dzieci.

W pierwszym rozdziale omówione zostały podstawowe pojęcia opisujące małżeństwo i rodzinę. S. L. Zalewska, stając na gruncie etyki katolickiej, definiuje małżeństwo jako naturalną, to znaczy nie przez ludzi ustanowioną i przez to również niezmienną wspólnotę osób złączonych sakramentalnym węzłem małżeńskim. Osoby te wspierają się w wypełnianiu powierzonych 
im zadań. Takie podejście sprzeciwia się współczesnym próbom redukowania wspólnoty małżeńskiej do fenomenu wyłącznie psychologicznego czy socjologicznego. Katalog zadań, jakie mają do wypełnienia małżonkowie, przedstawiono w drugim rozdziale. Autorka „rozpisuje” wymienione powyżej trzy sfery wspólnoty małżeńskiej na odpowiednie zadania szczegółowe. Trzeci rozdział poświęcono charakterystyce założeń metodologicznych przeprowadzonego przez autorkę w połowie lat dziewięćdziesiątych minionego stulecia (sic!) badania terenowego. W kolejnym, czwartym rozdziale przedstawiono wyniki tego badania. Autorka opisała i zinterpretowała w nim dane dotyczące wyszczególnionych w trzecim rozdziale zadań małżeńskich. Ze względu na zróżnicowanie metod - badanie sondażowe i studium indywidualnego przypadku - wyniki omówiono w osobnych podrozdziałach. Piąty i ostatni rozdział traktuje o syndromie pustego gniazda, który miało zdiagnozować przeprowadzone badanie.

Opublikowana przez S. L. Zalewską diagnoza syndromu opuszczonego gniazda jest obecnie, oczywiście, nieaktualna. Monografia powstała bowiem jako thumaczenie pracy dyplomowej obronionej na kierunku psychologia w roku akademickim 1995/1996. Widać to wyraźnie w wykazie literatury cytowanej, który odzwierciedla stan wiedzy z połowy lat dziewięćdziesiątych minionego stulecia. Brakuje w nim pozycji współczesnych. Mimo to walorem recenzowanej pracy jest to, że został $\mathrm{w}$ niej uchwycony proces zmiany w określonym momencie historycznym. Nie jest to ani moment początkowy, ani końcowy. Jeszcze raz nawiązując do myśli I. Kanta, można stwierdzić, że zmiana jest wpisana $\mathrm{w}$ istotę współczesnego małżeństwa i rodziny. Autorka poszukuje jednak czegoś niepodlegającego przeobrażeniom. Na ślad tego spodziewa się natrafić, przyjmując jako główną hipotezę afirmację zależności między religijnością małżonków a głębią ich wzajemnych relacji. Wydaje się, że w tym „miejscu" udało się jej ująć specyficzną trudność analizowanego problemu. Pozwolę sobie wyrazić tę trudność za pomocą następującego pytania: jak pogodzić nieuniknioną zmienność relacji małżeńskich z niezmiennością sakramentalnej więzi łączącej małżonków? Współgranie obu tych komponentów jest we współczesnej kulturze coraz mniej zrozumiałym paradoksem, którego przybliżenie można znaleźć w monografii S. L. Zalewskiej. Nie jest to bynajmniej jedyny powód, dla którego warto się z nią zapoznać.

Dariusz Stępowski*

* Dr hab. Dariusz Stępkowski, prof. UKSW, jest kierownikiem Katedry Pedagogiki Ogólnej i Filozofii Wychowania na Wydziale Nauk Pedagogicznych Uniwersytetu Kardy- 


\section{Jarosław Michalski, Rzecz o takcie pedagogicznym nauczyciela, Warszawa: Wydawnictwo Akademii Pedagogiki Specjalnej, 2013, ss. 198.}

DOI: http://dx.doi.org/10.12775/PCh.2015.02।

Słowo „takt” używane jest w różnych sytuacjach życia codziennego, ponieważ związane jest z refleksją o człowieku, z doświadczaniem przez niego obecności drugiej osoby oraz podmiotowego współistnienia, współtworzenia rzeczywistości. Dlatego ma ogromne znaczenie w wielu obszarach ludzkiego funkcjonowania, między innymi w kulturze, w polityce, w gospodarce, w edukacji. Uczy w tych sferach nie tylko zasad dobrego wychowania, ale także uwzględniania uczuć drugiego człowieka oraz zachowania adekwatnego do zaistniałych okoliczności. Znaczenie tego terminu wciąż odkrywane jest w różnorodnych dyskursach, w tym również w dyskursach naukowych. Takt bywa różnie interpretowany przez przedstawicieli nauk humanistycznych, między innymi pedagogiki, filozofii, literatury, psychologii czy socjologii. Trzeba podkreślić, że synkretyczne ujęcie przyczynia się do wzbogacenia znaczeniowego tego pojęcia.

Zastanówmy się, jak takt jest rozumiany na gruncie pedagogiki, w szczególności w zakresie pedeutologii? Należy zaznaczyć, że badacze nadal poszukują czynników, które decydują o wartości nauczyciela oraz wpływają na efektywność jego działalności. Zastanawiają się: kim jest?; kim powinien być?; kim chce być nauczyciel? Z analizy myśli pedeutologicznej wynika, że właściwości osobowościowe warunkują powodzenie w zawodzie pedagogicznym. Dlatego poznanie i ustalenie najbardziej wartościowych cech nauczyciela ma ogromne znaczenie zarówno w zakresie jego pragmatycznych zobowiązań, jak i w percepcji własnej osoby. Moga one przyczynić się do większej samoświadomości, oceny własnej postawy oraz stosunku do wykonywanej profesji, jak i tworzenia planów dalszego rozwoju zawodowego. Wśród tych właściwości osobowych niezwykle ważne miejsce zajmuje takt pedagogiczny. O jego znaczeniu w pracy pedagogicznej przekonywali między innymi: Johann Friedrich Herbart ${ }^{1}$, Stefan

nała Stefana Wyszyńskiego w Warszawie. Adres: Wydział Nauk Pedagogicznych UKSW, ul. Wóycickiego 1/3, budynek nr 15, 01-938 Warszawa; e-mail: d.stepkowski@uksw.edu.pl.

1 Johann Friedrich Herbart, Pedagogika ogólna wywiedziona z celu wychowania (Warszawa: Gebethner i Wolff, 1912). 